\title{
Fernando Pessoa's The Book of Disquiet. Imagination, Reality and the Pleasure of Masking and Dreaming
}

\section{Rodica Grigore ${ }^{1}$}

The Portuguese writer Fernando Pessoa complicates the idea of fictionality, by underscoring the fact that the personality of Soares (the fictional author of The Book of Disquiet) is neither his own nor completely different, and showing how Pessoa was constrained by his own creations and creativity. This essay, "Fernando Pessoa's The Book of Disquiet. Imagination, Reality and the Pleasure of Masking and Dreaming" explores the implications of the heteronyms that the author created in order both to express and hide himself from the external world. Soares, according to Pessoa, soars above his immediate surroundings, and even his corporeal grounding, into the realm of the tangible, the imagination. Dreams, consciousness, imagined realities, make up the existence of the fictional author of The Book of Disquiet, since he himself is a dream, an imagined personality that has taken on an actual reality, an instantiation of a poet's self-consciousness. However, Soares seems to invert the process of ironic Socratic dialectic; he does not need Socrates to strip his life of immediacy and even corporeality in order to get him to breathe ethereal air. Instead, Soares is quite literally half in the immediate, the real, and half in the "mediate", the imagined, since he is only half himself. Soares leaps from imagined sunset to imagined love, asserting a reality he knows he does not have. In this way, he consciously unknows himself, reveling in the "poetry of the twilight of disillusion". [Article copies available for a fee from The Transformative Studies Institute. E-mail address: journal@transformativestudies.org

Website: http://www.transformativestudies.org (C2011 by The Transformative Studies Institute. All rights reserved.]

KEYWORDS: Reality, Imagination, Fiction, Solitude, Alienation, Estrangement, Mask, Pseudonym, Heteronym, $20^{\text {th }}$ Century Literature.

\footnotetext{
${ }^{1}$ Rodica Grigore is a senior lecturer in comparative literature at "Lucian Blaga" University of Sibiu, Romania. Address correspondence to: Rodica Grigore, Lucian Blaga University of Sibiu, Romania; e-mail: rodica_grigore@yahoo.com.
} 